\title{
Dwelling services, with an emphasis on imputed rent in the European Union*
}

Magdolna Komolafe Hungarian Central Statistical Office,

Hungary

E-mail:

magdolna.komolafe@ksh.hu
Imputed rent and actual rent paid by the tenant are inherent in dwelling services. The study presents the estimation method of imputed rent in national accounts. Without imputing this item, gross domestic product (GDP) figures would be skewed. The author examines the distribution of imputed rent within the European Union (EU) member states, and describes the housing conditions therein; she also identifies the theory behind the differential distribution of owneroccupied dwellings among member states and analyses EU housing conditions. Using the Esping-Andersen (1990) welfare state typology and national accounts figures, EU member states are clustered based on their imputed rents. Some of the findings align with the Esping-Andersen typology, while others do not. Convergence of liberal, universalistic and conservative welfare regimes is found with respect to housing tenure. In the paper the Mediterranean welfare regime constitutes a separate cluster, just as EU 'newcomers' (formerly socialist member states) that showed a completely different character with respect to housing tenure. The study presents two methods (the stratification and the user-cost methods) by which imputed rent was determined for the EU member states. Macro- and microlevel aspects are considered when analysing dwelling services of EU member states, depending on the scope and depth of the examination. The two data sources are based on different

Keywords: methodologies thus satisfy different research purposes. Nonetheless, by leveraging these two data sources, one can achieve deeper insights into EU housing conditions.

* The views expressed herein are solely those of the author.

Regional Statistics, Vol. 8. No. 1. 2018: 168-186; DOI: 10.15196/RS080107 


\section{Introduction}

Imputed rent is the main component of dwelling services; it is the amount that a homeowner would pay to himself or herself if he/she were to rent that home. The estimation of imputed rent of an owner-occupied dwelling is one of the specialities of national accounts: according to the System of National Accounts (SNA) and the European System of Accounts (ESA), imputed rent is indispensable, as it constitutes a part of GDP. In fact, in the absence of imputed rent, it is impossible to compile the sequence of national accounts. It is essential that this item be included in the main aggregates of the economy, because a general shift from rented dwellings to private ownership may provide a misleading or inaccurate picture of the economy's performance.

Countries can vary significantly in terms of the ratio of owner-occupied to rented dwellings, and in the absence of this information, international comparisons will be distorted. Additionally, having a net imputed rent tends to reduce inequality within a country, or among countries. In any case, imputation data are needed, because housing tenure changes over time in any country and in the absence of said data, intertemporal comparisons of production and consumption vis-à-vis housing services would be biased. The European Commission's task is to ensure that member states use comparable methodologies when estimating the components of their national accounts. GDP and gross national income (GNI) are the basic measures that play important roles in determining transfers payable through the EU budget, and so the importance and implications of having sound imputed rent information are clear.

With the production approach, the value of the imputed services of owneroccupied dwellings appears as an output of production; however, with the expenditure approach it appears as the final consumption of households. In the income approach of national accounts, finally, it appears as one of the most significant components of household-level disposable income. In emphasizing the need to impute non-market items, inspiration can be drawn from the Report by the Commission on the Measurement of Economic Performance and Social Progress, also known as the Stiglitz Report (Stiglitz et al. 2009). The report suggests that, when examining welfare, the household-level perspective should predominate, and a broader measure of household income should be taken into account. It has been proven on the basis of Gini index values that when one takes into consideration imputed rent items, inequalities among countries decrease, as do those within a single country (Juntto-Reijo 2010, Törmalehto-Sauli 2013, 2017).

Several hypotheses exist concerning the magnitude of tenure status or of dwelling ownership within a country. Some suggest that the magnitude relates to the country's level of economic development - which is to say, the more developed a country's economy is, the higher its percentage of dwelling ownership will be. Others assume that the share of owner-occupied dwellings is influenced by other factors, like cultural or socioeconomic factors, institutional or historical backgrounds, and the legal system of the country.

Regional Statistics, Vol. 8. No. 1. 2018: 168-186; DOI: 10.15196/RS080107 
This study aims to determine the degree to which housing conditions and housing tenure differ among countries, and to cluster EU member states in terms of their imputed rent (as drawn from national accounts figures). I use both macro- and micro-level data to compare the member states in terms of imputed rent and housing tenure; macro-level data comprise national account data, while micro-level data are obtained from the statistics on income and living conditions (EU-SILC) database (Eurostat 2014), available from the Eurostat homepage (https://ec.europa.eu /eurostat/data/database).

In the paper, first the theory that explains the rationale behind the distribution of home ownership in the EU is discussed. Then the two main valuation methods on imputed rent (namely, the stratification method and the user-cost method) are introduced, and the macro- and micro-level data sources used for the examination are presented. After that, EU housing conditions are analysed based on the aforementioned macro- and micro-level data, emphasizing the ways in which the two main data sources are used. Finally, conclusions are drawn regarding the distribution of imputed rent versus housing tenure status.

\section{Rationales and theories behind the institutional dwelling services framework}

There are different rationales or theories behind the state of (and changes in) the share of home ownership across different countries. One would suppose that the possession of certain properties (dwellings) relate to the prosperity of a state: the higher the state's per-capita GDP is, for example, the higher the ratio of owneroccupied dwellings will be. However, research findings do not support this hypothesis. In fact, the opposite trend can be seen in the cases of Germany and Romania, where in spite of high-level economic performance, there are low proportions of owner-occupied dwellings, and vice versa. In exploring other explanations for this phenomenon, the following ideas can be found in the literature.

Juntto and Reijo (2010) undertook a methodological study related to imputed rent, based on Network for the Analysis of EU-SILC (Net-SILC) data. ${ }^{1}$ They suggest that every country has its own institutional framework for housing. Welfare regime typologies can provide some explanation vis-à-vis national housing conditions, cultures, and structures. Based on the work of Esping-Andersen (1990) and his colleague (Esping-Andersen-Myles 2009), welfare regime typologies can be used to categorize countries into groups, in terms of the relationships therein among the state, market, and family in housing provisions. These types of welfare regimes are the liberal, universalistic, conservative, and Mediterranean state regimes. These researchers have found in each country a strong correlation between its type of welfare regime and its housing framework. (One should bear in mind, however, that

${ }^{1}$ See Eurostat (2010).

Regional Statistics, Vol. 8. No. 1. 2018: 168-186; DOI: 10.15196/RS080107 
these categories were not primarily created to describe differences in institutional housing conditions.)

A liberal welfare regime is influenced predominantly by the market, and its housing policy is marginal. This regime supports the possession of private property, and there is a deep demarcation between the social and private rental sectors. The taxation system favours the private rental sector, and subsidies are predominantly means-tested benefits. In a liberal welfare regime, developed financing and housing market prevails, and household indebtedness is treated as something quite typical.

The main features of a universalistic welfare regime - often referred to as a Nordic or Scandinavian welfare regime - include the large share of the non-profit housing sector and the presence of high-level public subsidies. Housing provision allocations have no means testing. This is the most egalitarian regime of all.

In a conservative (or corporatist welfare) regime, the market's role is moderately determined by housing provision and financing. The proportion of owner-occupied dwellings is large. Family relationships tend to carry more weight with regard to housing services and house building than is typically seen in liberal or universalistic regimes. As the countries that belong to this regime group generally have high levels of industrialization, urbanization, and wealth, the share of dwellings inherited through intergenerational transfers is relatively high.

The Mediterranean welfare regime was not considered by Esping-Andersen as constituting a separate welfare regime, but later the typology was extended to feature this group. Compared to a conservative regime, family and kin are considered even more important in this regime, and intergenerational housing transactions are significant. The state does not play an important role in regulating the housing market or housing services through taxation or subsidization.

Among Esping-Andersen's original regime types, Central-Eastern European countries did not comprise a separate regime type, because at that time they were still economies in transition. The new member states (i.e. those that became EU members after 2004) can be characterized as having very high shares of owneroccupancy; a small social housing sector, mostly because of the intensive privatization process; and a small private rental sector. Within this regime, private homes are rarely sold, and so defining competitive pricing is nearly impossible. Additionally, new homes and mortgage loans are more difficult to obtain within these countries. By now, one can see that in many respects, Central-Eastern European countries constitute a separate type of welfare regime in terms of dwelling services.

\section{Estimation methods used to compile imputed rent}

The compilation of imputed rent is not a new phenomenon in the history of national accounts. The earliest version of SNA, published in 1953, states that the 'rental imputation accords with the rules given for other producers if account is taken of the fact that home

Regional Statistics, Vol. 8. No. 1. 2018: 168-186; DOI: 10.15196/RS080107 
ownership is regarded as a trade' (SNA 1953, p. 5.). Since then, all versions of the SNA (1993) treat owner-occupied dwelling services as falling under the auspices of production. The actual SNA 2008 describes in paragraph 6.34 that, although it constitutes an exception to the general exclusion of own-account service production, owner-occupiers' production of housing services for their own final consumption has always constituted a part of domestic output. In the ESA 2010 regulation, imputed rent is defined as a main component of real estate services: it describes in paragraph 3.75 that the output of services of owneroccupied dwellings is valued as the equivalent of tenant-occupied unfurnished dwellings. At the time of imputation, several factors should be taken into account, like location, neighbourhood amenities, as well as dwelling size and quality. A similar imputation is required for garages located separately but used by the owner of the dwellings, and holiday homes used for permanent living. Apart from SNA and ESA (1995, 2010), there are other European Commission regulations that describe the principles used to estimate dwelling services. One of them is a regulation that specifies the said principles and which took effect in $1995 .^{2}$ Until 2000, the EU member states comprised Austria, Belgium, Denmark, Finland, France, Germany, Greece, Ireland, Italy, Luxembourg, the Netherlands, Portugal, Spain, Sweden, and the United Kingdom. These member states' housing markets and housing conditions varied widely, but differed even more from those of the newcomers that acceded to the EU in 2004. The suggested and preferred method for imputing owneroccupied dwelling services was (and still is) the stratification method, which is based on actual rents. However, while self-assessment and the user-cost method were mentioned among the options, they received no special emphasis at that time. The other important specific law was Commission Regulation No. 1722/2005, which focused on the changed situation of the enlarged EU. In 2004, following the accession of Central-Eastern European member states, the composition of housing tenure status shifted towards a higher rate of owner occupancy, relative to a 'comparatively' tiny private rental sector. The main difference between the two aforementioned documents is that while the former did not specify the circumstances under which the second best method - namely, the user-cost method - should be applied, the latter gave more detailed rules for its application. Two other methods have been mentioned, but there has been no suggestion that they be applied. Under the first, the self-assessment method, an owner-occupier estimates the potential rent for his or her dwelling, but the estimation is treated as subjective. Under the second, the administrative assessment method, the potential rent is determined by third parties like the government, generally for fiscal purposes. In the following, I discuss the stratification and user-cost methods in detail.

\section{Stratification and regression method}

To compile the output of dwelling services, it is recommended that EU member states apply the stratification method while using actual rents, where 'rent' means the

${ }^{2}$ See Commission Decision No. 95/309 (European Commission 1995).

Regional Statistics, Vol. 8. No. 1. 2018: 168-186; DOI: 10.15196/RS080107 
fee that must be paid for an unfurnished dwelling. Public-owned and furnished dwellings might be included in the imputation, on the condition that amounts that deviate from those of privately owned unfurnished flat can be eliminated. To define the rental value, there are three sets of variables that should be examined. The first set concerns the characteristics of the dwellings and buildings, like the size of the dwelling, the number of rooms, and dwelling amenities. The existence of a bathroom, balcony, central heating, air conditioning, garage, lift, or swimming pool, the position of the dwelling, and the number of dwellings within the building are all relevant factors. The environmental characteristics constitute the second set of variables. Proximity to the economic centre, the beauty of the landscape and the surrounding green area, access to transport facilities, access to shops/schools/pharmacies, and the reputation and security of the district all are factors that contribute to the rental value amount. The third set of variables can be summarized as socioeconomic factors, which include the rental regulations of central and local governments, the age of the tenancy agreement, the housing tenure status, and the rental policy of the landlord. These are all factors that play an important role in shaping the rent amount.

Use of the capital value of dwellings for stratification purposes is considered adequate, because the capital value reflects all the important dwelling characteristics. The ratio of capital value to actual rent can be applied if the ratio is proven stable and if the value of capital is based on an objective assessment. The method can be used with physical stratification criteria. The weakness of this method is that the number and descriptions of strata can differ among EU member states. However, certain basic criteria (e.g. dwelling size and location) should be applied everywhere.

By using multiple regression analysis, one can assess the influence of individual variables. The explanatory power of a variable can be quantified by a correlation coefficient, thus allowing one to rank characteristics in terms of importance. In this way, the selection of important variables can help stratify the housing stock. Commission Regulation No. 1722/2005 claims that tabular analyses or special statistical techniques should be used to derive significant stratification criteria. For estimation purposes, at least 30 cells should be produced, and three size classes and two location types should be distinguished. The number of variables is acceptable if the multiple correlation coefficient reaches 70 per cent.

\section{User-cost method}

The second preferred method is the user-cost method. According to the formerly cited regulation, the user-cost method can be applied if both of the following conditions are met: 1 . Privately rented dwellings must represent less than 10 per cent of the dwelling stock; 2. Disparity between private and other paid rents exceeds a factor of 3 . In the late 1990s, these two conditions were seen in many Eastern European states.

In 1998, 13 formerly socialist countries signed their intention to accede to the EU. Realizing that the stratification method was not feasible for these candidate countries,

Regional Statistics, Vol. 8. No. 1. 2018: 168-186; DOI: 10.15196/RS080107 
Eurostat organized two projects to provide technical assistance to national statistical offices in implementing the user-cost method. The evolution of the user-cost method in satisfying the needs of candidate countries is described in detail by Katz (2009), who explains how it became clear that the stratification method was not applicable in these cases, given the small and unrepresentative private rental sectors of the formerly socialist countries. The user-cost method reverses the normal accounting procedure and compiles the output from its components; in essence, it is the reverse of the usual imputation for dwelling services based on the stratification method.

The components of the user-cost method are intermediate consumption, the consumption of fixed capital, other (net) taxes on production, and the net operating surplus. Intermediate consumption contains the expenditure on ordinary maintenance and repair that an owner-occupier incurs in decorating and repairing the dwelling, in areas not typically carried out by tenants. Net insurance paid by the dwelling owners and the financial intermediation services indirectly measured (FISIM) also comprise parts of intermediate consumption. According to ESA 2010 (paragraph 14.01), the amount of FISIM is the difference between the reference rate and the rate actually paid to depositors and charged to borrowers, where the reference rate of interest is the rate at which both the lender and the borrower are happy to conclude a deal. According to Katz (2009), in Eastern European countries, intermediate consumption is between 15 and 25 per cent of the output of owner-occupied dwellings.

The consumption of fixed capital (CFC) is estimated based on the stock of fixed assets and the expected average economic life of the different categories of those goods (ESA 2010, paragraph 3.141). The preferred means of estimating the CFC is the perpetual inventory method, which has a long tradition in Western European countries. At the time of their accession, it was recommended to the Eastern European countries that they implement the method as early as possible. The CFC represents on average 30-40 per cent of the output of dwelling services.

Other (net) taxes on production concerning dwelling services refer to those taxes payable that relate to the possession of the dwelling (e.g. taxes on the ownership of a building or land) and which are independent of the quantity or value of its production. Across Eastern European countries, the share of this item compared to that of the other components is relatively low.

The most important component of the imputed rent is the net operating surplus, which represents nearly 50 per cent of output. By convention, it is calculated by applying a constant real annual rate of return to the net value of the stock of owner-occupied dwellings at current prices. To ensure comparability among countries and to avoid net operating surplus volatility due to different rates of return, it was set by a Commission regulation that the real rates of return on both dwellings and lands were 2.5 per cent.

Table 1 is a sample worksheet compiled by the World Bank, by which one can estimate expenditures on owner-occupied dwelling services by using the user-cost method. This worksheet is helpful in aggregating the main components by which one can derive the amount of imputed rent.

Regional Statistics, Vol. 8. No. 1. 2018: 168-186; DOI: 10.15196/RS080107 
Table 1

Worksheet for estimating expenditures on owner-occupied dwelling services, using the user-cost method $^{3}$

\begin{tabular}{l|l}
\hline \multicolumn{2}{c}{ Item description } \\
\hline Intermediate consumption \\
UC 01 & Expenditure on maintenance and repair of owner-occupied dwellings \\
UC 02 & Gross insurance premiums paid on owner-occupied dwellings \\
UC 03 & Insurance premium paid to owners \\
UC 04 & Net insurance premium paid by owners (UC 02 - UC 03) \\
UC 05 & Total intermediate consumption (UC 01 + UC 04) \\
\hline Other taxes on production \\
UC 06 & Taxes paid by owners on dwelling services \\
UC 07 & Taxes paid by owners on the value of owner-occupied dwellings and their associated \\
\\
UC 08 & land \\
\hline Consumption of fixed capital \\
UC 09 & Cotal taxes paid by owners (UC 06 + UC 07) \\
\hline
\end{tabular}

Net operating surplus

UC 10 Current market value of the stock of owner-occupied dwellings at the beginning of the year (including land)

UC 11 Current market value of the stock of owner-occupied dwellings at the end of the year (including land)

UC 12 Current market value of the stock of owner-occupied dwellings at mid-year (including land) ((UC $10+\mathrm{UC} 11) / 2)$

UC 13 Real rate of return on owner-occupied dwellings (including land), in per cent per annum UC $14 \quad$ Real net operating surplus ((UC 13* UC 12) / 100)

Expenditure on owner-occupied dwelling services

UC $15 \quad$ Expenditure on owner-occupied dwelling services (UC $05+\mathrm{UC} 08+\mathrm{UC} 09+\mathrm{UC} 14)$

Source: World Bank (2010).

\section{Data sources relating to imputed rent and housing conditions}

\section{Macro-level data sources}

By macro-level data, I primarily mean data that are based on national accounts or data acquired through aggregation. The most well-known macro-level data aggregated in the national accounts pertain to GDP, GNI, disposable income, and house-

${ }^{3}$ For more information on this worksheet, see http://documents.worldbank.org/curated/en/ 116491468180868626/pdf/905170WP003-030N0Box0385317B0PUBLIC.pdf, p. 9.

Regional Statistics, Vol. 8. No. 1. 2018: 168-186; DOI: 10.15196/RS080107 
hold consumption, inter alia. Macro-level data are compiled, among other things, by using different kinds of survey and administrative data, imputations, and leveraging expert estimations. In the case of imputed rent, the following data sources are typically used: housing census data, price index statistics, household budget survey data, and the annual reports of financial corporations. In national accounts, the scope of the reference population includes both private and institutional households, and so all resident households are taken into account. For the sake of comparability among countries, imputed rent compiled in the national accounts is frequently presented as a percentage of GDP or household final consumption expenditure (HFCE).

\section{Micro-level data sources}

Micro-level data refers to survey data collected from individuals, such as those gathered through household budget surveys. Concerning housing conditions, my main data source was the EU-SILC database, which was established in 2003 and is organized under Framework Regulation 1177/2003 accepted by the European Parliament and Council. EU-SILC is a multi-purpose instrument that serves as the reference source for statistics on income and living conditions. By using micro-level statistics like those in the EU-SILC, I was able to achieve deeper insights into not only the distribution of household categories, but also the housing conditions of the member states. As the data are gathered through household surveys, the EU-SILC offers diversified data related to housing conditions. The survey of the EU-SILC serves as a tool for collecting and compiling data and for monitoring the progress made towards fulfilling the goals of the Europe 2020 Strategy. EU-SILC is based on a common framework rather than a common survey, and is organized under a framework regulation that is used by all member states.

The EU-SILC framework comprises a list of target variables. Two kinds of variables exist in the database (primary and secondary variables), and both are gathered at the household and individual levels. Data pertaining to the primary variables are collected every year, while secondary-variable data are collected every five years (or even less frequently) in the so-called ad hoc modules related to specific topics. Concerning households and housing conditions, the database contains annual indicators, like 'imputed rent' (HY030G/HY030N) on net and gross bases, 'income from renting a property or land' (HY040G/HY040N), 'person responding to the household questionnaire' (HB070), 'person 1 responsible for the accommodation' (HB080), 'dwelling type' (HH010), 'tenure status' (HH020), and so on. The ad hoc module that collects information on dwelling circumstances is called the Housing Conditions Survey, and it was executed in 2007 and 2012.

The variables used in the housing conditions module prioritize the quality measures of housing; these include 'adequate electrical installations' (HC030), 'dwelling comfortably warm during winter time' (HC060), 'dwelling comfortably cool during summer time' (HC070), and 'accessibility of grocery services, banking

Regional Statistics, Vol. 8. No. 1. 2018: 168-186; DOI: 10.15196/RS080107 
services, postal services, public transport, and primary health care services' (HC090-HC130), among others.

The value of imputed rent calculated on the basis of micro-level data is examined in the proportion of adjusted disposable income, as part of the EU social indicators. The method by which it is calculated is not as strict as in national accounts, and the compilation method is more diverse across countries.

\section{Comparing macro- and micro-level data sources}

Using the two aforementioned types of data sources, we need to bear in mind that they illustrate different aspects of reality and are not interchangeable; furthermore, their comparability is limited (Eurostat 2013). Table 2 provides an at-a-glance comparison of the macro- and micro-level data sources used in the current study.

Table 2

Comparison of macro- and micro-level data sources

\begin{tabular}{l|l|l}
\hline Feature of the data source & \multicolumn{1}{|c|}{ Macro-level data source } & \multicolumn{1}{c}{ Micro-level data source } \\
\hline Population coverage & $\begin{array}{l}\text { Total resident population of } \\
\text { a country } \\
\text { Presenting main aggregates like } \\
\text { GDP, final expenditure, etc. }\end{array}$ & Private households \\
Regulation & $\begin{array}{l}\text { Its regulation is compulsory for } \\
\text { EU member states }\end{array}$ & $\begin{array}{l}\text { Its regulation is only a recom- } \\
\text { mendation and serves as a frame- } \\
\text { work }\end{array}$ \\
Forms of data collection & $\begin{array}{l}\text { Multiple sources like surveys, } \\
\text { administrative sources, expert } \\
\text { estimations, etc. }\end{array}$ & $\begin{array}{l}\text { EUth survey based on house- } \\
\text { hold budget survey }\end{array}$
\end{tabular}

In summary, in comparing the macro- and micro-level data aggregates, one can say that, owing to the fact that the compilation method for imputed rent in the national accounts is more strict and regulated by community law - not to mention that it goes through a more thorough checking process -, imputed rent as a macro-level aggregate is more reliable. However, it does have some deficiencies. For example, it cannot provide one with deeper insights into quality measures of a given country's distribution of housing services. One cannot gain sufficient background information relating to the quality and condition of buildings, the age and income groups of proprietors, and so on. At the same time, however, plenty of detailed information can be acquired from micro-level sources like the EU-SILC and other household surveys. In any case, national accounts figures as macro-level sources describe the total economy, whereas describing how distribution is shaped, micro-level sources are used.

Regional Statistics, Vol. 8. No. 1. 2018: 168-186; DOI: 10.15196/RS080107 


\section{Comparison of imputed rents and housing conditions across the EU}

A household's dwelling is an important element of its wealth, and for the majority of households it is one of the biggest expenditures. To compare dwelling services among European member states, I used both micro-level data and macro-level aggregates. In the research, national accounts figures have been used to examine the value of dwelling services as a whole. As a part of the sequence of national accounts, the values have been compared to important aggregates like GDP and the household final consumption expenditure (HFCE). Nevertheless, information can be obtained by using micro-level sources, and in this way, one can achieve deeper insights, for example, into the quality distribution of housing and indebtedness. This study, however, aims to highlight the main difference between the two data sources in terms of applicability.

\section{Comparison of imputed rent in the EU, using macro-level sources}

Using national accounts data, I created a ranking of EU member states with respect to the share of imputed rent for the year 2016 (see Figure 1). The value of owneroccupied dwelling services ranged from 57.3 per cent (in Germany) to 97.6 per cent (in Romania). Among the Western European member states, the shares are lower, while moving towards the Mediterranean and Eastern European member states, one can observe a gradual increase in the share values.

Figure 1

Ratio of actual and imputed rents in dwelling services, 2016

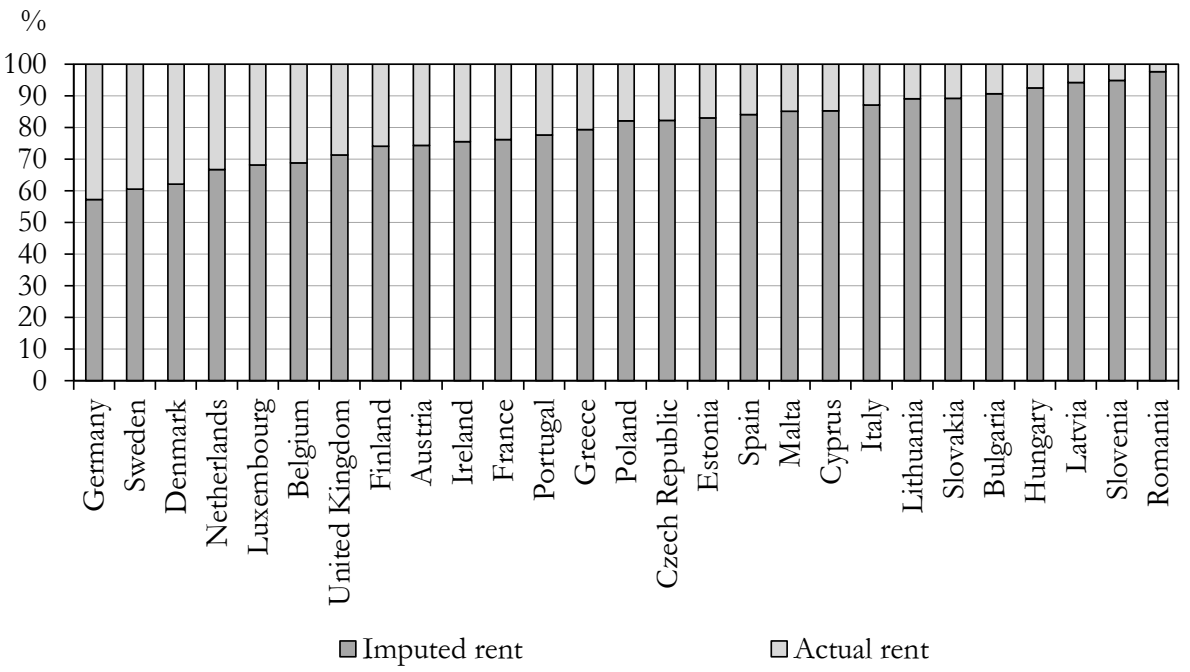

Note: The list of countries does not include Croatia.

Source: Eurostat database.

Regional Statistics, Vol. 8. No. 1. 2018: 168-186; DOI: 10.15196/RS080107 
In many of the EU member states, the share of imputed rent in total rent has been stable over time. However, in the cases of Ireland, Luxembourg, and the United Kingdom, there was an approximately 10-percentage-point decrease in the share of imputed rent between 2000 and 2016. Poland, Estonia, and Belgium each saw a slight decrease in the ratio, while the Czech Republic, the Netherlands, and Portugal sustained a bit of an increase. Despite its lowest share among the EU member states, Germany's number grew by 4.4 percentage points during this period. Table 3 presents the changes in the share of imputed rent across member states.

Table 3

Changes in the share of imputed rent in total rent

\begin{tabular}{|c|c|c|c|c|c|}
\hline EU member state & 2000 & 2005 & 2010 & 2015 & 2016 \\
\hline Germany & 52.9 & 54.2 & 55.3 & 57.0 & 57.3 \\
\hline Sweden & 59.9 & 61.0 & 61.3 & 60.5 & 60.5 \\
\hline Denmark & 61.5 & 60.8 & 61.2 & 62.2 & 62.2 \\
\hline Netherlands & 60.1 & 62.2 & 64.5 & 66.4 & 66.8 \\
\hline Luxembourg & 80.5 & 81.4 & 80.3 & 68.1 & 68.1 \\
\hline Belgium & 74.0 & 73.0 & 71.1 & 69.2 & 68.9 \\
\hline United Kingdom & 80.7 & 80.2 & 75.3 & 71.7 & 71.4 \\
\hline Finland & 71.8 & 71.8 & 74.0 & 74.1 & 74.1 \\
\hline Austria & 76.3 & 77.1 & 75.3 & 74.9 & 74.4 \\
\hline Ireland & 86.2 & 83.7 & 77.5 & 76.5 & 75.6 \\
\hline France & 76.1 & 76.8 & 76.7 & 76.2 & 76.2 \\
\hline Portugal & 73.2 & 75.1 & 77.2 & 77.7 & 77.7 \\
\hline Greece & 78.1 & 78.5 & 79.3 & 79.4 & 79.4 \\
\hline Poland & 90.6 & 76.6 & 80.5 & 81.6 & 82.2 \\
\hline Czech Republic & 74.9 & 77.7 & 80.0 & 82.1 & 82.3 \\
\hline Estonia & 91.5 & 88.4 & 88.9 & 83.3 & 83.0 \\
\hline Spain & 88.6 & 88.0 & 85.5 & 84.0 & 84.1 \\
\hline Malta & 90.4 & 91.7 & 86.4 & 85.2 & 85.2 \\
\hline Cyprus & 87.2 & 87.5 & 85.6 & 85.3 & 85.3 \\
\hline Italy & 85.2 & 86.6 & 86.7 & 86.9 & 87.1 \\
\hline Lithuania & 94.3 & 95.0 & 94.3 & 91.0 & 89.2 \\
\hline Slovakia & 92.8 & 88.9 & 89.0 & 88.9 & 89.2 \\
\hline Bulgaria & 88.9 & 93.3 & 92.2 & 90.3 & 90.6 \\
\hline Hungary & 94.5 & 93.8 & 93.7 & 92.7 & 92.5 \\
\hline Latvia & 85.6 & 93.6 & 93.2 & 94.2 & 94.3 \\
\hline Slovenia & 96.0 & 94.8 & 93.6 & 94.8 & 94.9 \\
\hline Romania & 99.7 & 96.1 & 95.5 & 97.6 & 97.6 \\
\hline
\end{tabular}

Note: The list of countries does not include Croatia.

Source: Eurostat database.

Regional Statistics, Vol. 8. No. 1. 2018: 168-186; DOI: 10.15196/RS080107 
Imputed rent is one of the most significant components of the HFCE, disposable income and GDP. Figure 2 shows the imputed rent (owner occupancy) in the share of GDP, as well as HFCE, across the EU member states in 2016.

Figure 2

Imputed rent as a percentage of GDP and HFCE, 2016

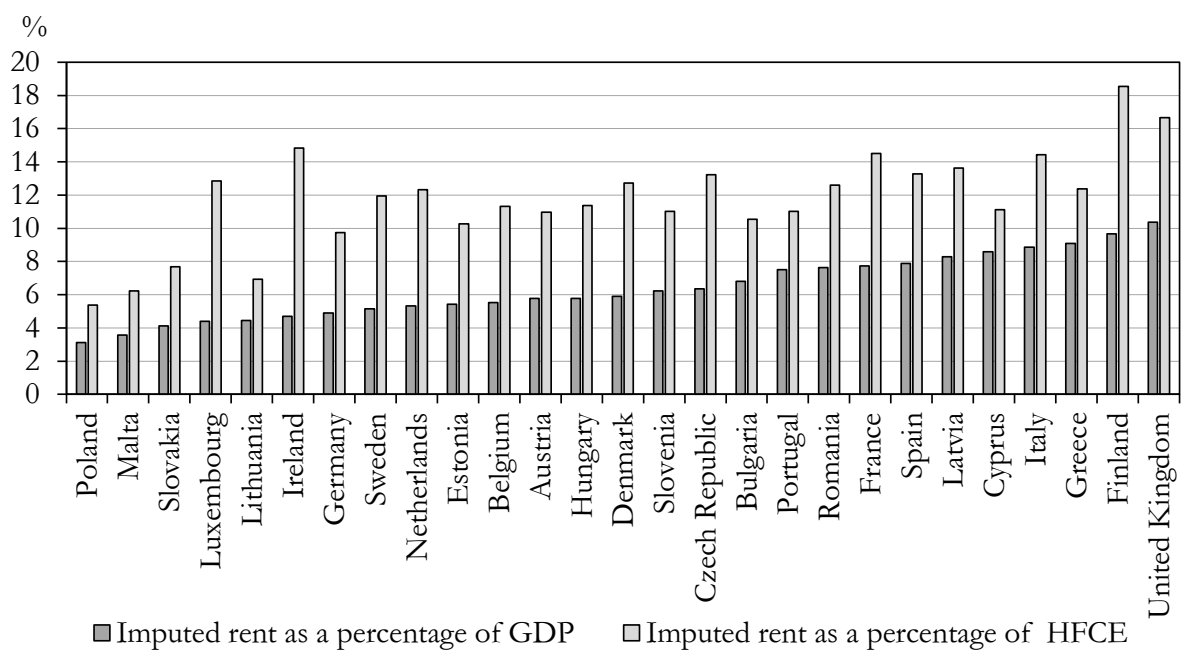

Note: GDP - gross domestic product; HFCE - household final consumption expenditure. The list of countries does not include Croatia.

Source: Eurostat database.

In 2016, imputed rent ranged from 3.1 per cent (in Poland) to 10.4 per cent (in the United Kingdom) of GDP. However, the measure of imputed rent shows a more diverse picture in the share of HFCE: whereas in Finland it reached 18.5 per cent, in Poland it hardly amounted to 5.4 per cent.

Figure 3 is a map showing the share of imputed rent in total rent across EU member states. Clearly, there are large variations across the EU in terms of owner occupancy, with the share of imputed rent ranging from about 57.3 per cent (in Germany) to above 97.6 per cent (in Romania). 


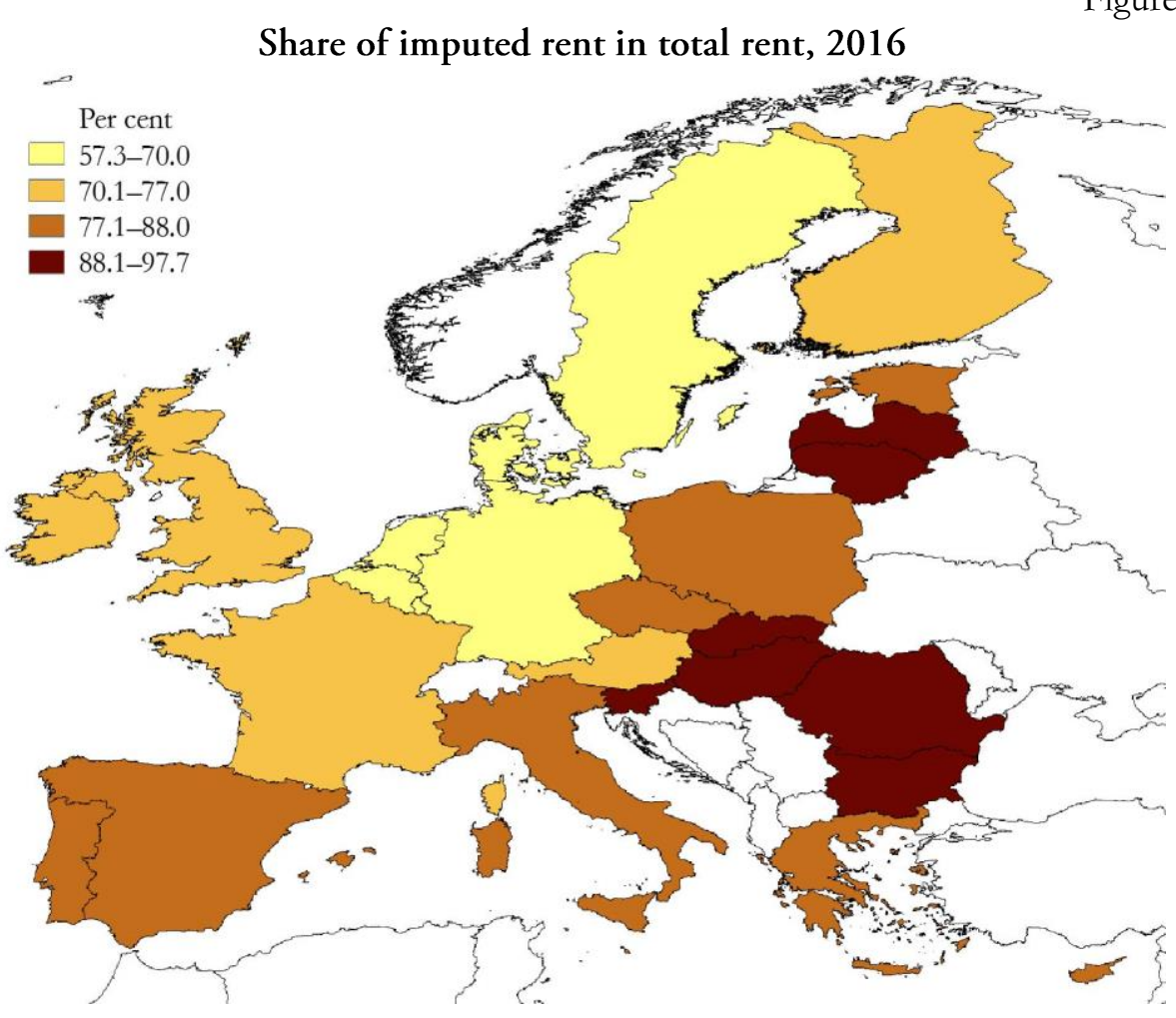

Note: The map is based on national accounts figures and shows EU member states except for Croatia. Source: Eurostat database.

With the help of macro-level data on imputed rent, I was able to identify the following four main groups:

- Scandinavian and Benelux member states with Germany;

- 'remaining' Western European member states;

- Mediterranean countries, together with three Central-Eastern European member states;

- rest of the formerly socialist member states.

In any case, I must concede that the value limits among the category groups were set up arbitrarily.

The four groups are somewhat similar to the welfare state typologies described by Esping-Andersen (1990) and Juntto-Reijo (2010). However, the liberal, universalistic, and conservative welfare regimes are gradually converging, largely because of the growing role of the market versus those of states and families. The share of owner occupancy ranged from 57.3 to 70.0 per cent across Northern European and Benelux member states, and in Germany (see Figure 3). In my ranking, Austria, Finland, France, Ireland, and the United Kingdom belong to the second group,

Regional Statistics, Vol. 8. No. 1. 2018: 168-186; DOI: 10.15196/RS080107 
where the owner-occupancy rate ranged from 70.1 to 77.0 per cent. However, the demarcation between the first and second groups is not clear, as the defining limits are not overly strict, and so a member state can easily move from the first group to the second one. In the third group, the dominance of the Mediterranean member states is obvious, but three formerly socialist member states - namely, Poland, the Czech Republic, and Estonia - are included. The state and family play more important roles in these member states, as it was discussed earlier. In considering the formerly socialist member states, a homogeneous group emerges and can be separated from the others. This type of regime did not exist in the typology of Esping-Andersen (1990), as he had set up his typology only for capitalist member states. The main characteristics of Eastern European states is that owner occupancy predominates, and tenancy is considered a temporary situation. In these countries, privatization of state- or local government-owned dwellings promote private ownership; private dwellings constituted - and continue to constitute - the most valuable component of a household's fixed assets, and ownership imbues a household with a sense of security.

\section{Comparison of housing conditions in the EU, using micro-level sources}

The use of a micro-level source (the EU-SILC database) allows me to undertake detailed examinations. By using this data source, I was able to achieve more indepth insights into certain topics on dwelling services, like the distribution of houses with a mortgage or loan, or with no such outstanding debt. Moreover, that database provides information on the distribution of rented dwellings where the tenant pays the market price versus a reduced price or lives rent-free.

Figure 4 illustrates the distribution of owner-occupied dwellings with or without an outstanding mortgage, and rents at market prices and at reduced prices (or free). In 2016, almost 70 per cent of households in the EU28 population owned their own homes, and more than 38 per cent of the owners had a mortgage or a housing loan. In line with data from the macro-level source, home ownership rates ranged from less than 52 per cent (in Germany) to more than 96 per cent (in Romania). Lower percentages of dwellings in Slovakia, Romania, and Bulgaria had outstanding mortgages; meanwhile, around 84 and 88 per cent of owners in Sweden and the Netherlands, respectively, held mortgages. More than 30 per cent of the EU population lived in rented dwellings, of which 65 per cent were paying market-price rent, and 35 per cent were either paying reduced-rate rent or were living rent-free. Finally, in Lithuania, Malta, Bulgaria, and Croatia, over 80 per cent of tenants were paying reduced-rate rent or lived rent-free, while in Sweden and Denmark more than 98 per cent of tenants were paying market-price rent.

Regional Statistics, Vol. 8. No. 1. 2018: 168-186; DOI: 10.15196/RS080107 
Figure 4

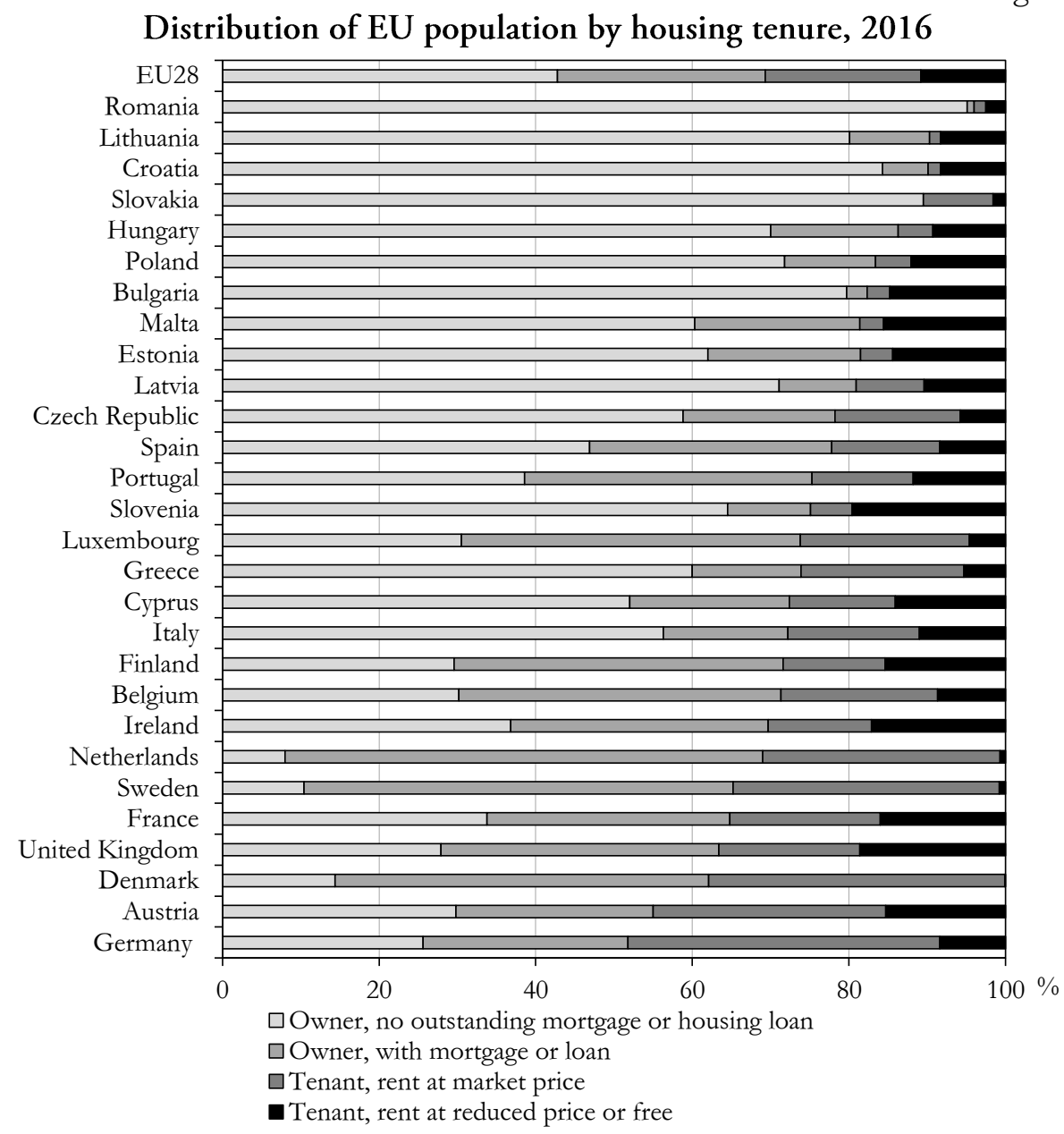

Source: Eurostat database (EU-SILC survey data on the distribution of population by tenure status, type of household, and income group).

By using micro-level data, it is possible to derive more detailed information on housing conditions. If I go beyond the tenure structure, considerable data exist visà-vis quality of living conditions, such as overcrowding or whether the interiors are well lit. Households with a leaking roof, without a bath/shower/indoor flushing toilet, or with a housing cost overburden rate can also be examined. In my study, I primarily focused on the distribution of dwelling services and the main applicability of the data sources, but further analysis can certainly be conducted with respect to quality measures.

Regional Statistics, Vol. 8. No. 1. 2018: 168-186; DOI: 10.15196/RS080107 


\section{Conclusions}

This study examined the distribution of imputed rent and housing conditions in the $\mathrm{EU}$, as derived using macro- and micro-level data. It also sought to identify those theories that explain differences in the distribution of owner-occupied dwellings in the member states, and as a result, four groups were established. Esping-Andersen, in his text The Three Worlds of Welfare Capitalism (1990), distinguishes three different welfare state types; however, since he had originally categorized only capitalist states, the formerly socialist states are not represented in his typology. His original welfare regime typology consisted of liberal, universalistic, and conservative regime types, and these were later accompanied by the Mediterranean welfare regime. By focusing on dwelling ownership and using the share of imputed rent based on national accounts data, I identified four main clusters: the Benelux and some Nordic member states, with Germany; the remaining Western European member states; the Mediterranean member states with three Central-Eastern European member states; and the rest of the formerly socialist member states. Nonetheless, the categories were set up somewhat arbitrarily. In spite of the similarities between my typology and that of Esping-Andersen, I found that the role of the market has been growing among EU member states, and that the formerly socialist member states constitute a separate category with respect to owner occupancy.

As imputed rent is a critical component of dwelling services, I presented two main estimation methods regarding the compilation of imputed rent: 1 . the stratification method is preferred for imputing owner-occupied dwelling services and is based on actual rents; and 2. the user-cost method that reverses the normal accounting procedure and compiles the output from its components (i.e. intermediate consumption, CFC, other (net) taxes on production, and net operating surplus).

My special aim was to highlight the appropriate use of macro- and micro-level data sources, by undertaking a brief analysis of the main applications of data sources. In this study, national accounts figures held utmost importance in determining the overall value of dwelling services. Housing conditions were analysed using both macro- and micro-level data sources, and it was found that while one could derive a general picture by aggregated national accounts, the use of EU-SILC micro-level data allows for deeper insights into EU housing conditions.

\section{REFERENCES}

Esping-Andersen, G (1990): The Three Worlds of Welfare Capitalism Princeton University, Polity Press, Princeton-Cambridge.

Esping-Andersen, G.-Myles, J. (2009): The Welfare State and Redistribution (unpublished) Authors homepage: http://dcpis.upf.edu/ gosta-espingandersen/materials/welfare_state.pdf (downloaded: July 2018)

European Commission (1995): Commission Decision No 95/309 of 18 July 1995 specifying the principles for estimating $d$ welling services for the purpose of implement-

Regional Statistics, Vol. 8. No. 1. 2018: 168-186; DOI: 10.15196/RS080107 
ing Article 1 of Council Directive 89/130/EEC, Euratom on the harmonization of the compilation of gross national product at market prices https://eurlex.europa.eu/eli/dec/1995/309/oj (downloaded: July 2018)

European COMMISSION (2003): Commission Regulation (EC) No 1177/2003 of the European Parliament and of the Council of 16 June 2003 concerning Community statistics on income and living conditions (EU-SILC) https://eur-lex.europa.eu/legalcontent/EN/TXT/?uri=OJ:L:2003:165:TOC (downloaded: July 2018)

European Commission (2005): Commission Regulation (EC) No 1722/2005 of 20 October 2005 on the principles for estimating dwelling services for the purpose of Council Regulation (EC, Euratom) No $1287 / 2003$ on the harmonisation of gross national income at market prices https://publications.europa.eu/ en/publication-detail/-/publication/fbe83178-0336-4aa1-99b8-1071bd7b9e99/ language-en (downloaded: July 2018)

European Council (1996): Council Regulation (EC) No 2223/96 of 25 June 1996 on the European system of national and regional accounts in the Community (consolidated version) http://eur-lex.europa.eu/legal-content/EN/TXT/?qid= 1425312413389\&uri=CELEX:01996R2223-20130701 (downloaded: July 2018)

EUROPEAN SYSTEM OF ACCOUNTS (ESA) (2010): Regulation (EU) No 549/2013 of the European Parliament and of the Council of 21 May 2013 on the European system of national and regional accounts in the European Union (text with EEA relevance) http://eur-lex.europa.eu/LexUriServ/LexUriServ.do?uri=OJ:L:2013: 174:0001:0727:EN:PDF (downloaded: July 2018)

Eurostat (1996): European System of Accounts - ESA 1995 Office for Official Publications of the European Communities, Luxembourg. https://ec.europa.eu/eurostat/documents/3859598/5826305/CA-15-96-001EN.pdf/aeec2852-bed2-46d2-9534-5859d3c911d5

Eurostat (2010): The Comparability of Imputed Rent Publications Office of the European Union, Luxembourg. https://doi.org/ 10.2785/56068

Eurostat (2013): European Household Income by Groups of Households European Commission http://ec.europa.eu/eurostat/documents/3888793/5858173/KS-RA-13023-EN.PDF/7e1dcfb2-2735-4334-9b0a-5a95af934b1d (downloaded: July 2018)

EUROSTAT (2014): EU statistics on income and living conditions EU-SILC methodologyStatistics explained http://ec.europa.eu/eurostat/statistics-explained/index.php /EU_statistics_on_income_and_living_conditions_(EU-SILC)_methodology (downloaded: July 2018)

Juntto, A.-Reijo, M. (2010): The Comparability of Imputed Rent, Eurostat https:/ / circabc.europa.eu/sd/a/a42391ca-4222-426b-9d73-f94ef9f41751/KSRA-10-022-EN-N (7).pdf (downloaded: July 2018)

KATZ, A. J. (2009): Estimating dwelling services in the candidate countries: Theoretical and practical considerations in developing methodologies based on a user cost of capital measure - Chapter 3. In: DIEWERT, W. E.-BALK, B.M.- FIXLER, D.Fox, K. J.-Nakamura, A. O. (eds.) Price and Productivity Measurement: Volume 1 - Housing pp. 33-50., Trafford Press, Bloomington.

SNA (1953): A System of National Accounts and Supporting Tables United Nations, Department of Economic Affairs, Statistical Office, New York.

Regional Statistics, Vol. 8. No. 1. 2018: 168-186; DOI: 10.15196/RS080107 
https://unstats.un.org/unsd/nationalaccount/docs/1953SNA.pdf (downloaded: July 2018)

SNA (1993): UN Department of Economic and Social Affairs, Statistics Division System of National Accounts 1993 Eurostat, IMF, OECD, UN, World Bank, BrusselsLuxembourg-New York-Paris-Washington, D.C. http://unstats.un.org /unsd/nationalaccount/docs/1993sna.pdf (downloaded: July 2018)

SNA (2008): System of National Accounts 2008, 2009 Edition Eurostat, IMF, OECD, UN, World Bank, Brussels-Luxembourg-New York-Paris-Washington, D.C. http://ec.europa.eu/eurostat/ramon/statmanuals/files/SNA2008.pdf (downloaded: July 2018)

Stiglitz, J. E.-Sen, A.-Fitoussi, J. P. (2009): Report by the Commission on the Measurement of Economic Performance and Social Progress http://www.stiglitz-senfitoussi.fr/documents/rapport_anglais.pdf (downloaded: July 2018)

Törmalehto, V-M.-Sauli, H (2013): The Distributional Impact of Imputed Rent in EU-SILC 2007-2010 Methodology and working papers, Eurostat, Luxembourg. http://ec.europa.eu/eurostat/documents/3888793/5857525/KS-RA-13-011EN.PDF/516f90a7-25d4-4359-a297-fa8311758a1a

Törmalehto, V-M.-Sauli, H (2017): The Distributional Impact of Imputed Rent in EU-SILC 2007-2012 - Monitoring Social Inclusion in Europe, 2017 Edition Eurostat, Luxembourg. http://ec.europa.eu/eurostat/documents/3217494/ 8031566/KS-05-14-075-EN-N.pdf/c3a33007-6cf2-4d86-9b9e-d39fd3e5420c

WORLD BANK (2010): Guidelines for the User Cost Method to Calculate Rents for Owner Occupied Housing International Comparison Program (ICP) 03.03. World Bank Group, Washington, D.C. http://documents.worldbank.org/curated/en/116491 468180868626/Guidelines-for-the-user-cost-method-to-calculate-rents-forowner-occupied-housing

http://ec.europa.eu/eurostat/data/database:

Distribution of population by tenure status, type of household and income group EU-SILC survey [ilc_lvho02] (extracted on 20.01.2018)

Final consumption expenditure of households (extracted on 27.02.2018)

GDP and main components (output, expenditure and income) [nama_10_gdp] (extracted on 27.02.2018)

Regional Statistics, Vol. 8. No. 1. 2018: 168-186; DOI: 10.15196/RS080107 